\title{
The Effect of Experiential Quality, Experiential Satisfaction, and Trust on the Interest to Revisit the Tourism Objects in Padang
}

\author{
Tri Andiani ${ }^{1}$ Yasri Yasri ${ }^{2}$ \\ 1Universitas Negeri Padang, Padang, Indonesia, $\square$ tribundaaaw@gmail.com \\ 2Universitas Negeri Padang, Padang, Indonesia, $₫$ yasrifeunp@gmail.com \\ "Corresponding Author
}

\begin{abstract}
This study aims to analyze the influence of experiential quality, experiential satisfaction and trust on interest to revisit to the tourism object in the city of Padang. The population of this study were all consumers who had visited a tourist attraction in the city of Padang with a total sample of 220 respondents. The analysis technique used is using Structural Equation Model (SEM) -Partial Least Square (PLS). The results of this study are Experiential quality has a positive and significant effect on experiential satisfaction, Experiential quality has a positive and significant effect on trust. This means that the higher the experiential quality which impacts on trust, Experiential quality positive and significant effect on the interest to revisit, Experiential satisfaction positive and significant impact on the trust, Experiential satisfaction positive and significant effect on the interest to revisit, the Trust has a positive effect and significant interest to revisit.
\end{abstract}

Keywords: experiential quality, experiential satisfaction, trust, interest to revisit

\section{Introduction}

Tourism is one of the sectors that has become the foundation for the Indonesian government to improve the economic conditions of the nation and state. The main role of the tourism sector in terms of the economy is as an increase in foreign exchange. The foreign exchange earnings from the tourism sector in 2017 amounted to 16.8 billion US dollars. This figure places the tourism sector to be ranked second in the country's largest foreign exchange contributor. This value is greater than 24.4 percent compared to 2016 amounting to US \$ 13.5 billion.

The increasing contribution of the tourism sector to the country's foreign exchange and an increase in the number of tourist visits indicate that the tourism sector continues to experience growth and has the potential to be developed.

West Sumatra is one of the provinces with a growing tourism sector, ranging from natural tourism, educational tourism, historical tourism, cultural tourism, shopping tours to culinary tourism which is the mainstay of tourism in Indonesia. one of the cities that is rich in the potential for natural beauty in West Sumatra is the capital of the Province of Padang City. Padang City is the largest city on the west coast of Sumatra Island, has an area of $694.96 \mathrm{~km}^{2}$ with geographical conditions bordering the sea and surrounded by hills with an altitude reaching 1,853 MASL. Only around 205,007 $\mathrm{km}^{2}$ of area is an effective urban area with a coastline of $68,126 \mathrm{~km}$ (Wikipedia, 2018).

Based on preliminary observations made at the Padang City Culture and Tourism Service, information on the number of domestic and foreign tourists in Padang City in 2011 - 2017 can be seen in Table 1 below:

Table 1 Number of Domestic and Foreign Tourists in Padang City in 2011-2017

\begin{tabular}{|c|c|c|c|c|c|}
\hline \multirow{2}{*}{ Year of } & \multicolumn{2}{|c|}{ Tourist } & \multirow{2}{*}{ Total } & \multicolumn{2}{|c|}{ Growth } \\
\hline & Foreign & Domestic & & Score & Percentage \\
\hline 2011 & 47.609 & $2,252,336$ & $2,299,945$ & & \\
\hline 2012 & 139,119 & $2,956,807$ & $3,104,926$ & 804,981 & 35.00 \\
\hline 2013 & 53,057 & 3.001 .306 & $3,054,363$ & $-50,563$ & $-1,63$ \\
\hline
\end{tabular}


Table Cont...

\begin{tabular}{cccccc}
\hline 2014 & 54,967 & $3,199,392$ & $3,254,359$ & 199,996 & 6.55 \\
\hline 2015 & 57,318 & $3,298,454$ & $3,355,772$ & 101,413 & 3.12 \\
\hline 2016 & 58,903 & $3,632,820$ & $3,691,723$ & 335,951 & 10.01 \\
\hline 2017 & 67,286 & $4,368,355$ & $4,435,661$ & 743,938 & 20,15 \\
\hline
\end{tabular}

Source: Padang Culture and Tourism Agency, 2017

Based on Table 1 above shows that the number of tourist visits in the city of Padang in 2012 to 2017 has fluctuated, which has made a significant increase and decrease in the number of tourists both domestic and foreign tourists, and not proportionally accompanied by percentage.

Furthermore, in 2017 there was an increase in the number of tourists by $20.15 \%$ from 2016 . The increase in the number of visitors was significant compared to the previous year, this suspected because the local government of Padang City together with the Office of Tourism and Culture made changes and structuring tourist attractions in Padang City on a large scale so that attractions in the city of Padang appear better, organized and with new faces that can attract tourists to come to the city of Padang.

But it will be a problem if there is no improvement in the quality of services, what will happen is that tourists easily move to other tourist destinations. The move of tourists to other tourist destinations is allegedly tourists are not satisfied and do not believe in these tourist destinations. While customer who get satisfaction while in a tourist destination in the City of Padang will be interested in returning to visit in the future and increase the frequency and volume of their visits.

On the other hand, tourism business competition and the development of tourism objects in other regions that offer unique characteristics or tourism managers must try to find other marketing strategies in order to compete with other regions. In addition, so that tourism businesses can continue to grow in terms of the number of tourist visits, they must create an attractive impression in their business to encourage tourists to come and come back again to visit the tourist destinations offered. Therefore, tourist destination managers must analyze and evaluate the experience gained by tourists when visiting these tourist destinations. The interest in revisit is the intensity of returning to tourist destinations twice or more, both towards the same tourist destination (Zeng et al, 2009).

Experiential quality is one of the factors that influence tourists interested in revisiting the tourist destiny they have visited (Chen \& Chen, 2010). The creation of good experiences for tourists can also encourage them to visit again. If tourists get a good experience when visiting a tourist destination, it is likely that consumers will return to visit the tourist destinations. According to Yuan and $\mathrm{Wu}(2008)$ getting some positive or negative experiences is the inevitable result of consuming products and services for customers in buying even though their needs and desires are different.

Based on the description, the author makes a study entitled The Effect of Experiential Quality, Experiential Satisfaction, and Trust on the Interest to Revisit to Tourism Objects in the City of Padang.

\section{Methods}

This study was conducted to analyze the influence of experimental quality, experiential satisfaction and trust on the decision to re-visit tourist attractions in the city of Padang. This study can be classified as explanatory research, namely research that explains the relationship of variables and tests the relationship between several variables through testing several hypotheses. Population is the whole of the characteristics or units of measurement results that are the object of research in a region and fulfill certain requirements related to research problems (Sekaran, 2009). The population characteristics in this study were:

a) Having an age of more than 17 years.

b) Have visited tourist attractions in the city of Padang in one year more than once.

c) Regarding the research sample, the sample size for SEM is a minimum of 10 times the number of arrows connected with latent variables (10 times the number of indicators) (Hair et al., 2014). From 
the results of calculations using the theory of Hair et al. (2014) the number of samples obtained in this study is the number of arrows (statement items) connected with latent variables, namely multiplied by 10 . So the number of samples in this study was set at 220 respondents.

\section{Results and Discussion}

The study used the SEM approach. The analytical tool used in analyzing SEM modeling and hypothesis testing using Partial Least square (PLS) with SmartPLS software version 3. Outer model analysis examines indicators of latent variables related to latent variables

\section{Outer Testing Model} Factor Loading

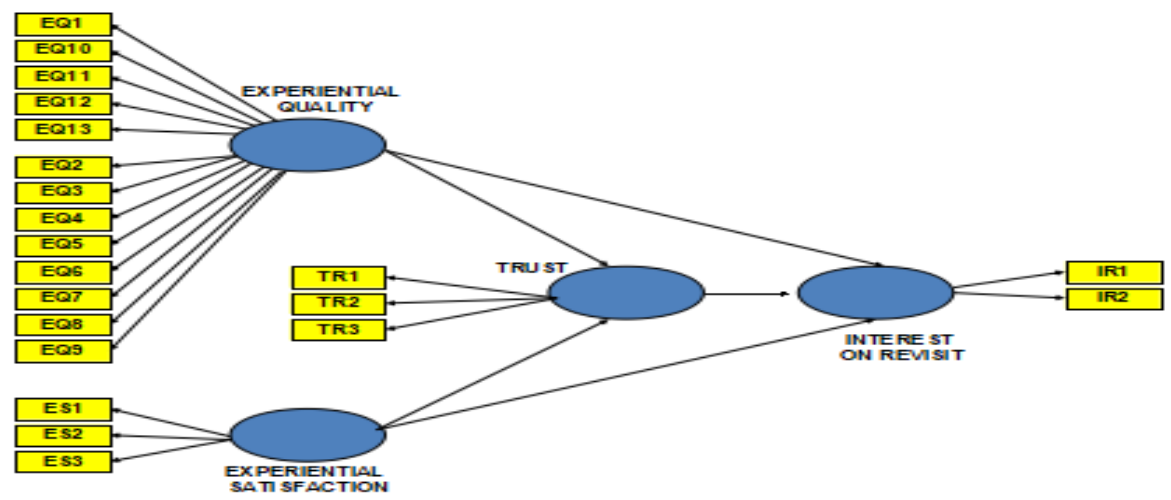

Figure 1.Structural Model Results

Source: Primary Data 2019 (Processed)

Figure 1 above shows the results of the structural model in this study which consists of three independent variables, one dependent variable and one intervening variable, as well as the value of outer loading on each of these variables. In experiential quality variable (X1) consists of 4 (four) indicators and 13 statements, experiential satisfaction (X2) consists of 3 (four) indicators and 3 statements, trust (X3) consists of 3 (three) indicators and 3 statements, and Interest in bekunjung back (Y) consists of 3 (three) indicators and 4 statements.

Average Variance Extracted (AVE)

Then testing the value of convergent validity can be seen from the value of AVE. This aims to measure the level of variance in a construct component collected from the indicator. The reconditioned AVE value must be more than 0.5 . The AVE value of each latent variable is as follows:

Table 2 Average Variance Extracted (AVE)

\begin{tabular}{lc}
\hline Variable & Average Variance Extracted (AVE) \\
\hline Interest on Revisit & 0.885 \\
\hline Experience Quality & 0.635 \\
\hline Experience Satisfaction & 0.660 \\
\hline Trust & 0.895 \\
\hline
\end{tabular}

Source: Data processed from Research Results (2019)

Based on Table 2 above can be seen the AVE value for all constructs> 0.5. Thus the measurement model convergent validity can be said to be valid.

\section{Composite reliability}

Composite reliability is a step used to test the reliability of indicators for a variable. An indicator can meet reliable requirements if it has a value composite reliability $>0.6$. Test reliability with methods composite reliability can also be strengthened by using the value of Cronbach's Alpha. A variable is said to be reliable if it has a Cronbach's Alpha value $>0.7$. The following are the cronbach's alpha values and values composite reliability of each variable: 
Table 3Cronbach's Alpha and Composite Reliability

\begin{tabular}{lcc}
\hline Variables & Cronbach's Alpha & Composite Reliability \\
\hline Interest on Revisit & 0.935 & 0.958 \\
\hline Quality Experience & 0.956 & 0.960 \\
\hline Experience Satisfaction & 0.758 & 0.853 \\
\hline Trust & 0.948 & 0.962 \\
\hline
\end{tabular}

Source: Data processed from Research Results (2019)

Based on Table 3 above, it can be seen that the values of each variable in composite reliability are above 0.6 and the value of cronbach's alpha is above 0.7. Thus these results indicate that each research variable has fulfilled the assessment criteria so that it can be concluded that the overall variables are said to be reliable.

\section{Inner Testing of the Model \\ R-Square( $\left.\mathbf{R}^{2}\right)$}

After testing the outer model that has been fulfilled, then the inner model is tested. Inner models can be evaluated by looking at $r$-square (indicator reliability). The value of $t$ statistics can be calculated by performing resampling with bootstrapping

Analysis of Variant $\left(\mathrm{R}^{2}\right)$ or a test of determination is to determine the influence of the independent variable on the dependent variable, the value of the coefficient of determination can be shown in the following table:

Table 4 R Square

\begin{tabular}{lcc}
\hline Variable & R Square & R Square Adjusted \\
\hline Interest on Revisit & 0.081 & 0.068 \\
\hline Experience Satisfaction & 0,008 & 0,004 \\
\hline Trust & 0,006 & 0,003 \\
\hline
\end{tabular}

Source: Data adapted from research (2019)

in Table 4 above this study can be seen that $R^{2}$ interest in discussing a return of 0.081 means that the variable trust, experiential quality and experiential satisfaction explain the variable interest in revisiting $8.1 \%$, the remaining $91.9 \%$ is explained by other extracts beyond those examined in this study. $\mathrm{R}^{2}$ trust of $0.8 \%$ means experiential quality and experiential satisfaction, explaining that the variables experiential satisfaction remaining of $99.2 \%$ are explained by other constructs beyond those examined in this study.

\section{Hypothesis testing}

Testing Hypotheses are carried out based on the results of testing the Inner Model (structural model) which includes parameter coefficients and t-statistics. To see whether a hypothesis can be accepted or rejected, among others, by paying attention to the significance value between extracts, $\mathrm{t}$-statistics, and p-values. These values can be seen from the results of bootstrapping. The rules of thumb used in this study are hypotheses that have a positive beta coefficient with a significance level of p-value $0.05(5 \%)$ that the results of hypothesis testing are based on beta values and p-value of 0.05 (5\%). It can be concluded that :

1. The results of the first hypothesis test are positive and $p$-value $=0,000$. This shows that experiential quality has a positive and significant effect on experiential satisfaction.

2. The second hypothesis test results are positive and $p$-value $=0.002$. This shows that experiential quality has a positive and significant effect on trust.

3. The third hypothesis test results are positive and $p$-value $=0.004$. This shows that experiential quality has a positive and significant effect on interest in revisiting.

4. The results of the fourth hypothesis test are positive and $p$-value $=0.039$. This shows that experiential satisfaction has a positive and significant effect on trust. 
5. The fifth hypothesis test results are positive and $p$-value $=0.013$. This shows that experiential satisfaction has a positive and significant effect on interest in returning.

6. The results of the sixth hypothesis test are positive and $p$-value $=0.019$. This shows that the trust has a positive and significant effect on the interest in returning.

\section{Discussion}

\section{The Effect of Experiential Quality on Experiential Satisfaction}

Based on the results of the analysis showed that experiential quality has a positive effect on experiential satisfaction in tourist destinations in the city of Padang. When a person feels that the service experience they have is higher than his expectations, they will be satisfied. In the assumption that quality and satisfaction are different constructs, there appears to be no clear message in the literature about the causes and qualities of quality, and which of the two constructs is a better predictor of the intention of the perpetrator ( $\mathrm{Wu} \&$ Cheng, 2017).

This research is in line with the research conducted by Wu \& Cheng, (2017); Wu \& Li (2017) argue that the quality of experience is the beginning of the experience of satisfaction. Because the quality of experience is cognitive evaluation, perceptions of experience quality have a positive result of the experience of satisfaction, which in turn can lead to the intention of the beneficial actor.

\section{The Influence of Experiential Quality on Trust}

Based on the analysis results show that experiential quality has a positive effect on trust in tourist destinations in the city of Padang. When a person feels that their service can be higher than his expectations, and they will get a pleasant experience with the quality of the service, so they will be satisfied, that satisfaction will make tourists believe in the tourist destinations they visit.

This research is in line with the research conducted by Chenet, Dagger, \& Sullivan, (2010); Gounaris \& Venetis (2002) which states that experiential quality influences trusts. Based on the concept of Consumer Behavior theory (Kotler, 2003), consumers usually learn from their past experiences, and future behavior is predicted based on past behavior. When the past experience is fun, on a particular brand, consumers will show more consistent behavior over time towards the brand (Tjahyadi, 2006).

\section{Effects of Experiential Quality on Revisit Interests}

Based on the results of the analysis, it was found that experiential quality had a positive effect on the interest in revisiting the tourist destinations of Padang city. Quality of service is now one of the most important in the business. The model that has been formulated for measuring the quality of SERVQUAL services. However, the concept underlying SERVQUAL is service experience, which is based on functional aspects (Chen \& Chen, 2010). Quality of experience tends to refer to the whole service rather than based on attributes. Experiential quality focuses on assessing the quality of services they receive. Perception of experiential quality is subjective. Quality experience allows tracking customer experience and key things from time to time, and can act as an important marketing metric. When tourists get good experience with the quality of service while visiting tourist destinations, they will allow them to visit again, and they will likely be loyal. Customer loyalty is the result of consistently positive emotions towards the experience of tourists when visiting.

There are not many studies that explain the relationship between experiential quality to request a return visit. However, Wu \& Ai (2016) once conducted research examining experiential quality affecting the interest in revisit.

\section{The Influence of Experiential Satisfaction on Trust}

Based on the results of the analysis shows that experiential satisfaction has a positive effect on trust in the tourist destinations of the city of Padang. Consumption experience is the most important source of trust in a brand because through experience there is a learning process that allows the formation of associations, thoughts and conclusions that are more relevant to the personal consumer or individual (Erna, 2008).

This research is in line with research conducted by Kantsperger \& Kunz (2010) arguing that satisfaction is the main antecedent of trust. Yeh and Li (2009) found that satisfaction has a strong impact on trust. 


\section{The Effect of Experiential Satisfaction Revisit Interests}

Based on the results of the analysis shows that experiential satisfaction has a positive effect on the interest in revisit the tourist destinations in the city of Padang. Research in marketing shows the intention to repeat purchases depending on the level of satisfaction of visitors with their experience of products or services (Sim \& Lee, 2013). If visitors are satisfied, they will tend to continue buying.

This research is in line with the findings of a study conducted by Loureiro \& González (2008). Furthermore, according to Petrick, Morais \& Norman (2001), the desire to travel in the future is influenced by their attitude towards good past experiences with little risk. While $\mathrm{Wu} \& \mathrm{Li}(2014)$ that experience satisfaction has a significant influence on behavioral intention in the rural tourism industry.

\section{The Effect of Trusts on Revisit Interests}

Based on the results of the analysis, it shows that trusts have a positive effect on interest in revisiting the Padang tourist destinations, according to Grewal, Hardesty \& Iyer (2004), repurchase intentions will be on consumers with trust. Also, where there is trust, there is an intention to accept deficiencies based on positive expectations. In general, consistently repeat purchases. Because of the uncertainty (Gounaris, 2005) notes trust as an important factor that influences repurchase behavior because it binds relationships between suppliers and visitors. Anderson \& Srinivasan (2003) identified that trust seems to be very important for creating behavioral intentions when the level of risk is high.

This research is in line with the research conducted by Chinomona (2016), if customers do not trust the company, they will not place the first purchase, let alone the next purchase. After the first purchase, trust is one of the things that is responsible for consumer commitment in making a second or third purchase (and with the same company) and, in general, consistently repeats purchases.

\section{Conclusions}

Based on the results of the research outlined in the previous chapter, the following conclusions can be drawn:

1. Experiential quality has a positive and significant effect on experiential satisfaction. This means that the better experiential quality increasingly influences experiential satisfaction.

2. Experiential quality has a positive and significant effect on trust. This means that the higher the experiential quality the more influential the trust.

3. Experiential quality revisiting has a positive and significant effect on interest in. This means that the better the quality of experiential influence the more the interest in revisiting.

4. Experiential satisfaction has a positive and significant effect on trust. This means that the higher the experiential satisfaction increasingly influences the trust.

5. Experiential satisfaction revisiting has a positive and significant effect on the interest in. This means that the higher experiential satisfaction has an effect on the interest in revisit.

6. Trust has a positive and significant effect on interest in returning. This means that the higher the trust the more influential the interest in revisit.

\section{References}

Abdillah, W., \& Jogiyanto, H. M. (2009). Konsep dan Aplikasi PLS (Partial Least Square) untuk penelitian empiris. Yogyakarta: Badan Penerbit Fakultas Ekonomi.

Badan Pusat Statistik (BPS) Kota Padang. (2017). Kota Padang Dalam Angka. Padang: ISSN: 0215-3769, Nomor: 13710.1803.

Chen, C. F., \& Chen, F. S. (2010). Experience qualiti, perceived value, satisfaction, and behavioral intentions for heritage tourists. Tourism Management, 3191), 29-35. doi:10.1016/j.tourman.2009.02.2008.

Chenet, P., Dagger, T. S., \& O'Sullivan, D. (2010). Service quality, trust, commitment, and service differentiation in business relationships. Journal of Service Marketing, 336-346, ISSN: 0887-6045.

Chinomona, R. (2016). Brand Comunication, brand image and brand trust as antecedents of brand loyalty in Gauteng Province of South Africa. African Journal of Economic and Management Studies.

Erna, F. (2008). Merek dan Psikologi Konsumen Implikasi pada Strategi Pemasaran. Yogyakarta: Graha Ilmu. 
Gounaris, S. P. (2005). Measuring service quality in B2B services: An Evaluation Of The SERVQUAL Scale Vis -A The INDSERV Scale. Journal of Service Marketing, Vol. 19,pp. 421-35.

Gounaris, S. P., \& Venetis, K. (2002). Trust in industrial service relationships:Behavioral consequences, antecedents and the moderating effect of the duration of the relationship. Journal of Services Marketing, 16(7), 636.

Grewal, D., Hardesty, D. M., \& Iyer, G. R. (2004). The effects of buyer identification and purchase timing on consumers' perceptions of trust, price fairness, and repurchase intentions. Jurnal Interac. Marketing, 18 (4) hal: 8-100.

Hair, J. F., Black, W. C., Babin, B. J., Anderson, R. E., \& Tatham, R. L. (2006). Multivariate data analysis(6th ed.). Upper Saddle River, NJ: Prentice Hall.

Kantzperger, R., \& Kunz, W. H. (2010). Consumer trust in service companies: A multiple mediating analysis. Journal of Managinf Service Quality, 20(1), 4-25.

Kotler, P. (2003). Manajemen Pemasaran, edisi kesebelas. dicetak di Indonesia: PT. Tema Baru (alih bahasa; Drs. Benyamin Molan).

Laureiro, S. M., \& Gonzales, F. J. (2008). The importance of quality, satisfaction, trust, and image in relation to rural tourist loyalty. Journal of Travel \& Tourism Marketing, 25, 117-136. doi:10.1080/10548400802402321.

Petrick, J. F., Morais, D. D., \& Norman, W. C. (2016). An Examination of the Determination of the Determinants of Entertainment Vacationers, Intentions to Revisit. Journal of Travel Research, 40, 41-48. http;//dx.doi.org/10.1177//004728750104000106.

Sekaran, U. (2009). Metode Penelitian Untuk Bisnis. Jilid 1. Edisi 4. Salemba Empat, Jakarta. https://doi.org/10.1016/j.compedu.2017.01.003

Tjahyadi, R. A. (2006). Brand trust dalam konteks loyalitas merek: Peran karakteristik merek, karakteristik perusahaan dan karakteristik hubungan pelanggan-merek. Jurnal Manajemen, Vol. 6, No. 1.

Wikipedia. (n.d.). Retrieved September 11, 2018, pukul 07:55, from https://id.wikipedia.org/wiki/Kota_Padang

Wu, H. C., \& Cheng, C. C. (2017). What drives green advocacy? A case study of leisure farms in Taiwan. Journal of Hospitality and Tourism Management, 33, 103-112. doi:10.1016/j.jhtm.2017.10.008.

Wu, H. C., \& Li, T. (2017). A study of experiential quality, perceived value, heritage image, experiential satisfaction, and behavioral intentions for heritage tourists. Journal of Hospitality $\mathcal{E}$ Tourism Research, 41, 904-944. doi:10.1177/1096348014525638.

Wu, H. C., Ai, C. H., \& Cheng, C. C. (2016). Synthesizing the effects of green experiential quality, green equity, green image and green experiential satisfaction ongreen switching intention. International Journal of Contemporary Hospitality Management, 28(9), 2080.

Yeh, Y. S., \& Li, Y. M. (2009). Building trust in m-commerce: Contributions fromquality and satisfaction. Online Information Review, 33(6), 1066e1086.

Zeng, Fue Hu, Zuohao Chen, \& Yang Zhilin (2009). Determinants of Online Service Satisfaction an Their Impact on Behavioural Intention. Total Quality Managemen. Vol 20, No 9, 953-969 